\title{
Literasi Metode Penelitian dan Bisnis Teknologi Kreatif di Era New Normal
}

\author{
Roymon Panjaitan ${ }^{\mathrm{a}, 1, *}$, Myra Andriana ${ }^{\mathrm{b}, 2}$,Tantik Sumarlin ${ }^{\mathrm{b}, 3}$, Sindhu Rakasiswi ${ }^{\mathrm{b}, 4}$,Yuli Fitrianto ${ }^{\mathrm{b}, 5}$ \\ ${ }^{\mathrm{a}, \mathrm{b}}$ Universitas Sains dan Teknologi Komputer, Jl. Majapahit 605, Semarang, Indonesia \\ ${ }^{1}$ roymon@stekom.ac.id *; ${ }^{2}$ myra.andriana@ stekom.ac.id; ${ }^{3}$ tantiksumarlin@yahoo.co.id ; ${ }^{4}$ sindhu@@ $@$ stekom.ac.id; ${ }^{5}$ \\ yuli_f@stekom.ac.id \\ * corresponding author
}

\section{ARTICLE INFO}

Article History

Received,31-12-2020

Revised,17-01-2021

Accepted,20-01-2021

Keywords

Impact of Covid-19;

MSMEs:

Innovation Opportunities;

Technology;;

\begin{abstract}
The Covid-19 pandemic that hit the world including Indonesia had an impact on all aspects, one of which was the economic aspect. MSMEs are the most affected, where 50\% of MSMEs are forced to go out of business because economic activities are stopped suddenly, and demand decreases. MSME turnover has dropped dramatically by around 40\%-70\%. Business people, especially MSMEs, have to start adapting to the new normal to maintain their business. At this webinar, various solutions will be given to the confusion of the community, especially MSME entrepreneurs, where they can choose the tips and solutions offered that are suitable to be applied according to their fields to survive and even grow during a pandemic, starting from business opportunities, to tips and tricks for using the right technology that can support MSME programs. The material in this webinar was delivered by 5 resource persons who are experts in their fields. The implenetation of this activity is carried out through the Zoom application and Live Youtube, with a total of 514 participants from various professions and MSME players. Webinar participants are given the opportunity to conduct questions and answer after all the resource persons have delivered their material. Participant who attend and fill in attendance receive certificates and material that are presented in this webinar.
\end{abstract}

\section{PENDAHULUAN}

Dampak Pandemi Covid-19 telah mempengaruhi seluruh aspek tatanan kehidupan, baik aspek ekonomi, kesehatan, pendidikan, pariwisata, dan lain sebagainya. Hampir rata rata seluruh bisnis usaha bisnis mikro kecil dan menengah (UMKM) terdampak Covid-19 [1]. UMKM menjadi yang paling terdampak saat pandemi karena UMKM lebih banyak menghasilkan produk makanan, minuman, industri kreatif dan hasil pertanian (dimana merupakan sektor yang paling terdampak). Selain itu, UMKM sangat tergantung pada penjualan, karena pendapatan cenderung bersifat harian dan UMKM adalah industri yang paling dekat dengan konsumen akhir.

Sebesar 50 persen pelaku usaha mikro kecil dan menengah (UMKM) menutup usahanya akibat Covid-19, berdasarkan laporan survei Asian Development Bank (ABD). Temuan survei Abd sejalan dengan yang dilakukan oleh Kemenko UKM, di mana penjualan UMKM paling terdampak. Sekitar 40-70 persen omzet UMKM turun [2]. Di Indonesia, UMKM merupakan industri yang sangat signifikan karena memiliki kontribusi yang tinggi terhadap penyerapan tenaga kerja dan pendapatan domestik bruto. Pada 2018, jumlah UMKM Indonesia sebesar 64.194.057 unit, atau 99\% dari seluruh skala pasar. Penyerapan pekerjaan berjumlah 116.978.631, atau 97\% dari keseluruhan penyerapan tenaga kerja di Indonesia. Kontribusi 66,97 persen terhadap produk domestik bruto [3].

Salah satu lembaga pendidikan Universitas Sains dan Teknologi Komputer (Universitas STEKOM) yang respon terhadap bisnis usaha mikro kecil dan menengah (UMKM). LP2M Universitas STEKOM menyelenggarakan seminar atau webinar 
pengabdian online dengan tema Literasi Metamorfosis : Metode Penelitian Literasi dan Metode Bisnis Teknologi Informasi Eksperimental pada Generasi New Normal untuk era baru kebiasaan hidup akibat pandemi Covid-19, di mana tema ini membutuhkan diskusi ilmu lintas bidang antara bidang Teknik Komputer, Manajemen dan Akuntansi.

Program PPM ini juga sekaligus sebagai solusi terhadap kebingungan masyarakat khususnya pengusaha UMKM, dimana mereka dapat memilih kiat-kiat dan solusi yang ditawarkan yang cocok untuk diterapkan sesuai dengan bidang mereka untuk tetap bertahan bahkan bertumbuh di masa pandemi, mulai dari peluang-peluang usaha, hingga tips dan trik penggunaan teknologi yang tepat yang dapat mendukung program-program UMKM. Program ini difokuskan kepada UMKM pengguna digital aplikasi bisnis yang berada di wilayah Jawa Tengah.

Berdasarkan survei yang dilakukan sebelumnya, dimasa pandemi ini terdapat beberapa permasalahan yang dihadapi oleh UMKM. Permasalahan tersebut diantaranya penelitian, peluang usaha, inovasi hingga pemanfaatan teknologi yang seharusnya dapat diterapkan untuk mendukung dan memberikan nilai tambah pada produk-produk usaha mereka. Webinar ini bertujuan untuk memberikan pandangan kepada masyarakat pada umumnya dan pelaku UMKM pada khususnya tentang kondisi perekonomian dalam menghadapi masalah-masalah tersebut yang timbul akibat adanya pandemi COVID-19.

Dengan diakannya kegiatan webinar ini diharapkan masyarakat memahami kondisi perekonomian di masa pandemi dan new normal, dapat memanfaatkan peluang usaha di masa pandemi, serta masyarakat dan UMKM dapat memanfaatkan teknologi dengan tepat dan bijak untuk meningkatkan dan memberi nilai tambah pada produk-produk mereka.

Target luaran yang ingin dicapai adalah bertambahnya pemahaman masyarakat tentang keadaan ekonomi akibat pandemi, mengetahui celah-celah yang dapat dimanfaatkan untuk dapat bertahan, menngetahui potensi-potensi usaha yang justru naik di masa pandemi, serta mengetahui penggunaan tekologi yang tepat sehingga dapat menghasilkan produkproduk yang inovatif.

\section{PELAKSAAAN DAN METODE}

Metode daring dalam bentuk webinar dipilih dalam kegiatan pengabdian masyarakat ini. Kegiatan webinar dilakukan sekali, dan dapat dilanjutkan dengan konsultasi jika ada pelaku UMKM yang menginginkan. Bila diperlukan dapat pula diberikan pelatihan pada pelaku UMKM. Webinar merupakan penggabungan dari kata web dan seminar, dimana diartikan sebagai kegiatan seminar yang menggunakan web atau internet [4]. Dipilihnya webinar dalam kegiatan pengabdian masyarakat, karena sangat sesuai di implementasikan dalam kondisi pandemi COVID 19. Presentasi adalah alternatif bagi peserta untuk menunjukkan pengetahuan mereka dalam periode waktu elevasi fisik saat ini kepada peserta. Papan diskusi adalah tutorial, diskusi, atau kelas master yang dilakukan oleh media yang berbeda secara online atau online dan dihadiri oleh beberapa peserta lain dari berbagai daerah yang berinteraksi langsung melalui dokumenter atau percakapan [5].

Peserta mendaftar secara gratis untuk memasuki sesi melalui linkage kuesioner online yang diberikan dengan mengetikkan nama pengguna, agensi, pekerjaan, nomor ponsel, dan alamat email mereka. Selanjutnya peserta akan mendapatkan link meeting ID Zoom beserta password serta link youtube yang digunakan untuk mengikuti kegiatan webinar melalui alamat email. Perangkat lunak kamera dan live streaming melalui konten Video digunakan untuk memfasilitasi lokakarya. Mereka diminta untuk mengunduh aplikasi untuk peserta yang ingin memasuki webinar melalui Zoom. Peserta akan mendapatkan e-certificate yang dikirim oleh akun setelah menghadiri lokakarya. 
Untuk menarik minat dan meningkatkan kuantitas peserta, dilakukan kegiatan promosi. Di beberapa saluran sosial lainnya, seperti Facebook, Instagram, Whatsapp, dan situs web universitas, upaya mendiseminasikan pengabdian ini adalah dengan memposting pamflet.

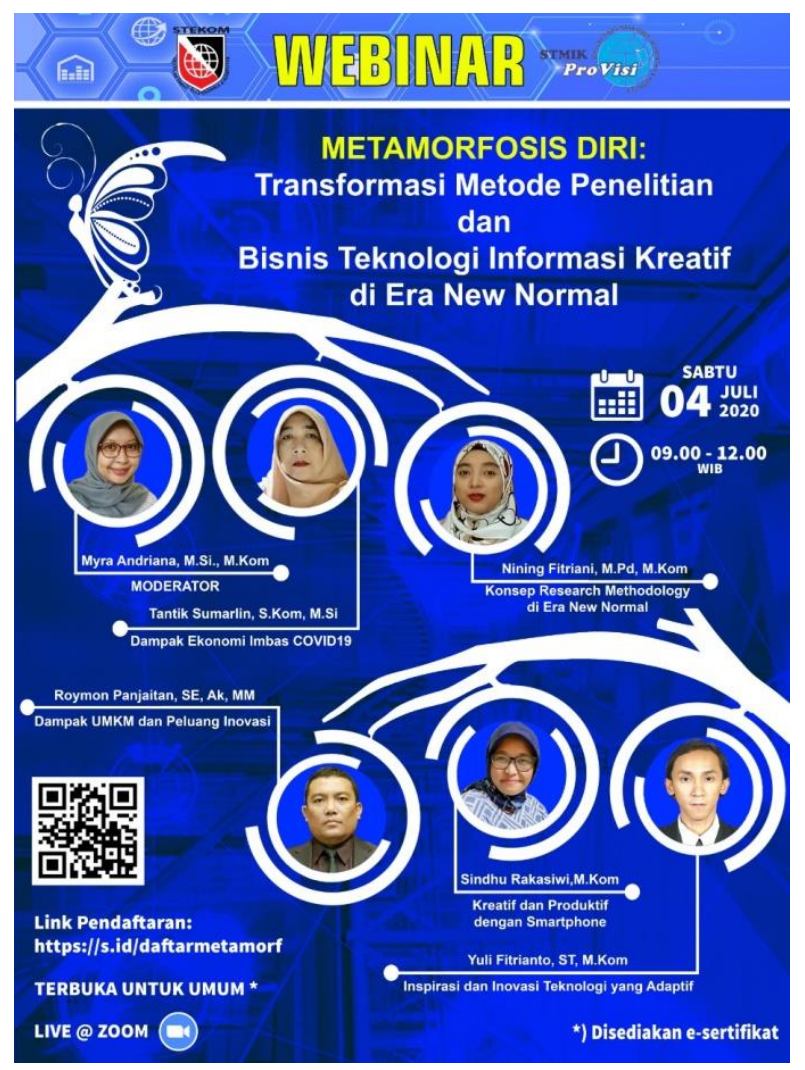

Gambar 1. Pamflet

\section{HASIL DAN PEMBAHASAN}

Webinar pengabdian masyarakat berlangsung pada hari Sabtu 04 Juli 2020. Kegiatan webinar dilaksanakan selama 3 jam mulai pukul 09.00 WIB hingga 12.00 WIB, dengan tema Metamorfosis Diri: Transformasi Metode Pengujian dan Industri Telekomunikasi Informasi Inovatif di Era New Normal.

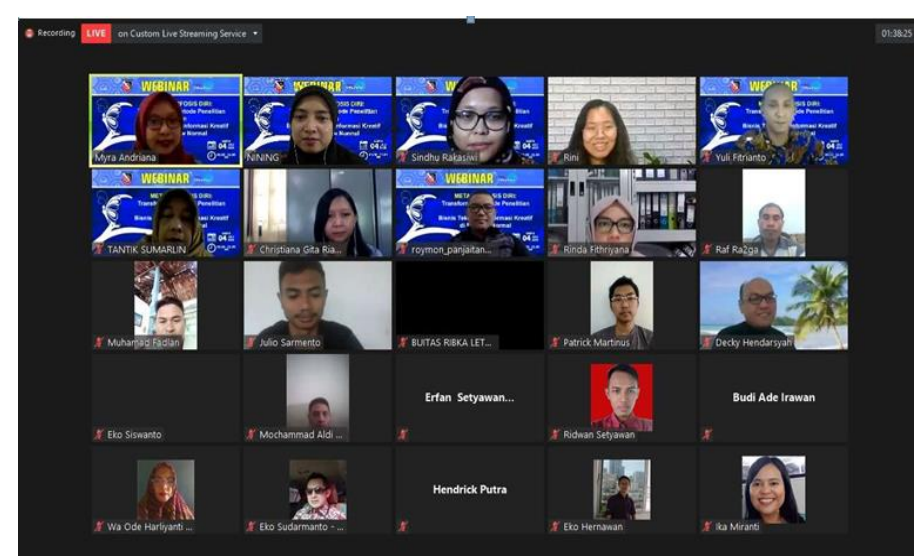

Gambar 2. Pelaksanaan Kegiatan Webinar 
Pola pelaksanaan program seminar online (webinar) dilakukan dengan menggunakan cara pemaparan materi melalui presentasi dan demo aplikasi dengan tapilan yang menarik beserta penjelasannya. Acara ini dimoderatori oleh Myra Andriana, M.Si., M.Kom dengan lima orang pemateri. Pemateri pertama oleh Roymon Panjaitan, S.E., Ak., M.M. dengan materi dampak UMKM dan peluang Inovasi. Pemateri kedua oleh Tantik Sumarlin, S.Kom.M.Si dengan materi Dampak Ekonomi Imbas Covid 19. Pemateri ketiga oleh Nining Fitriani, M.Pd., M.Kom. dengan materi Konsep Research Methodology di Era New Normal. Pemateri keempat oleh Sindhu Rakasiwi, M.Kom dengan materi Kreatif dan Produktif dengan Smatrphone. Pemateri terakhir oleh Yuli Fitrianto, S.T., M.Kom dengan materi Inspirasi dan Inovasi Teknologi yang Adaptif. Berikut ini merupakan uraian materi yang disampaikan oleh pembicara dalam kegiatan webinar.

\section{Dampak Ekonomi Covid-19}

Kasus Covid-19 terus meningkat di Indonesia dan di seluruh dunia. Implikasi tersebut mempengaruhi semua aspek, salah satunya aspek ekonomi, seperti jatuhnya indeks bursa saham, turunnya nilai tukar rupiah, dan sulitnya UMKM untuk tetap berbisnis. Pada 2 Maret 2020, perdagangan Indeks Harga Saham Gabungan (IHSG) turun 91,46 poin ke level 5.361,25, atau 1,68 persen. Di level Rp 3.000, IHSG juga sudah mencapai posisi jenuh selama delapan tahun terakhir. Pada 23 Maret 2020, biaya produksi dolar AS mencapai Rp 17.000 per dolar AS untuk lima bank besar tersebut. Rupiah di set di Rp16.608 per dolar AS oleh kurs referensi Jakarta Interbank Spot Dollar Rate atau JISDOR. Statistik itu juga merupakan yang terendah sejak krisis Juli 1998. Rupiah justru membaik 0,45 persen keesokan harinya ke level Rp16.500 per dolar AS.

50 persen industri mikro kecil dan skala (UMKM) menutup usahanya karena Covid-19, berdasarkan laporan survei Asian Development Bank (ABD). Pengamatan survei Abd sejalan dengan yang dilakukan oleh Kementerian UKM, di mana penjualan UMKM paling terdampak. Sekitar 40-70\% sangat berkurang dalam omset UMKM. Salah satu akibat yang ditimbulkan dari turunnya omset penjualan adalah pelaku UMKM tersebut kesulitan untuk membayar bunga dan cicilan. Untuk mengantisipasi permasalahan tersebut, pemerintah mengambil beberapa kebijakan bagi UMKM diantaranya:

a) Program restrukturisasi pinjaman selama 6 bulan, dimana para pelaku UMKM diberikan subsisi bunga 6 persen untuk usaha kecil mikro, dan 2-3 persen untuk usaha menengah.

(b) Pemerintah dapat dengan mudah menanggung pajak penghasilan akhir sebesar 0,5 persen (PP 23/2018) bagi UMKM untuk jangka waktu 6 bulan.

(c) Pembayaran diskresi pokok dan bunga dengan mempertimbangkan seluruh skema KUR yang terdampak COVID-199

(d) Pemberian potongan dan/atau penundaan pembayaran jalur perjanjian kredit atau sewa hingga Rp10 miliar untuk jangka waktu 1 tahun, termasuk bagi UMKM dan pekerja informal.

\section{Peluang Inovasi}

Di saat pandemi Covid-19 masyarakat harus mau dan mampu untuk beradaptasi pada kebiasaan baru atau sering disebut dengan era new normal. Tidak terkecuali dunia bisnis khususnya untuk UMKM. Banyak peluang usaha baru yang muncul akibat dari adanya pandemi Covid-19. Jika dilihat dari produk yang paling dicari antara bulan MaretApril 2020, Tokopedia dan Bisnis.com melaporkan bahwa masker, disenfektan, air purifier, vitamin, dan hand sanitier menduduki peringkat pertama. Sabun dan peralatan mandi serta rempah, makanan dan minuman menduduki peringkat kedua dan ketiga. 
Yang perlu dilakukan di era new normal saat ini adalah menumbuhkan jiwa kewirausahaan. Dengan adanya jiwa kewirausahaan semangat dan motivasi untuk menjadi wirausaha mudah untuk dikembangkan [6]. Selanjutnya adalah dengan membuat keunikan terhadap suatu produk, tentunya disesuaikan dengan kebutuhan dan kondisi masyarakat di era new normal saat ini. Dimana kesehatan menjadi fokus utama, tuntutan untuk melakukan physical distancing (jaga jarak) yang salah satunya membatasi masyarakat untuk pergi keluar rumah. Lakukan diferensiasi atau diversivikasi produk, serta empelajari dan memanfaatkan teknologi menjadi hal penting saat ini, dimana masyarakat banyak yang memanfaatkan online produk untuk mengurangi kegiatan di luar rumah. Contoh usaha yang muncul pada era new normal saat ini diantaranya Wae Seppang, yaitu minuman herbal dalam kemasan, Moringga Tea, merupakan minuman herbal daun kelor, serta hand sanitizer herbal.

\section{Konsep Research Methodology di Era New Normal}

Metodologi penelitian merupakan hal yang cukup menarik dibahas saat pendemi Covid-19. Banyak peneliti di berbagai bidang yang melakukan penelitian untuk mengetahui dampak yang ditimbulkan dari adanya wabah global ini. Salah satu yang terpenting dalam penelitian adalah pengumpulan data. Data yang dikumpulkan selanjutnya akan dianalaisis untuk memperoleh hasil dari penelitian yang dilakukan. Pengumpulan data dapat dilakukan melalui beberapa cara diantaranya melalui kuesioner atau angket, melalui interviu, melalui observasi, dan melalui dokumentasi.

Di era new normal saat ini untuk melakukan pengumpulan data masyarakat dapat menggunakan berbagai macam teknologi yang tersedia. Pemanfaatan teknologi ini mendukung kebijakan pemerintah, dimana masyarakat diminta untuk melakukan physical distancing serta membatasi aktivitas diluar rumah [7]. Salah satunya adalah aplikasi google, yang dapat digunakan untuk banyak aplikasi. Formulir Google memiliki aplikasi seperti membuat formulir pengumpulan data warga, membuat formulir untuk mendapatkan informasi dari eksperimen tesis, membuat kuis atau pemutaran ulang online, mencoba melakukan survei kinerja staf, pendaftaran atau formulir pendaftaran online, dll. Dengan Google, orang dapat dengan cepat dan nyaman mendapatkan data yang mereka inginkan.

\section{Kreatif dan Produktif dengan Smatrphone}

Pengguna smartphone selalu meningkat setiap tahunnya. Peningkatan penggunaan smartphone tersebut semakin tinggi saat pandemi Covid-19 sekarang ini. Hal tersebut disebabkan sebagian besar aktivitas di segala aspek saat ini dilakukan secara online. Pemanfaat smartphone diantaranya sebagai sarana komunikasi, sumber informasi, berlajar, bekerja, bisnis, dan hiburan. Tidak selamanya penggunaan smartphone menimbulkan dampak positif, ada beberapa dampak negatif yang mungkin muncul karena penggunaan smartphone seperti menggangu produktifitas, menimbulkan kecanduan, dan menyebabkan berkurangnya interaksi sosial.

Jika dimanfaatkan dengan baik, smartphone dapan memberikan manfaat yang cukup besar seperti mempermudah komunikasi, meningkatkan pengetahuan, tersedianya teknologi yang lebih canggih, meningkatkan kemampuan dalam mengatur waktu, sebagai media hiburan (penghilang stress). Beberapa aplikasi seluler yang membuat penggunanya lebih inovatif dan efisien, diantaranyaCuriosity, Feedly, Sience Journal, Solo Lern, Mimo, Google Form, Evernote, Craftsy, dan lain sebagainya. Beberapa tips agar dapat memanfaatkan smartphone dengan positif yaitu gunakan aplikasi yang menunjang aktivitas, hapus aplikasi yang tidak terlalu penting, serta gunakan aplikasi untuk membatasi pemakaian paket data. 


\section{Inspirasi dan Inovasi Teknologi Adaptif}

Tahun 2019 yang lalu gencar diperkenalkannya era revolusi industri 4.0, dimana teknologi digital dan dunia internet semakin digunakan secara luas. Penerapan artificial intelligence atau kecerdasan buatan juga semakin masif diterapkan di berbagai hal. Awal tahun 2020 tepatnya di akhir bulan Maret, dimana banyak orang masih berusaha untuk menyesuaikan diri dengan revolusi industri 4.0 tersebut, tiba-tiba di luar prediksi muncul wabah atau pandemi di Indonesia yang disebabkan oleh virus, yang disebut-sebut berasal dari kota Wuhan di negara Cina, yang dikenal dengan COVID-19. Perkembangan pandemi ini sangat memprihatinkan, hampir semua kalangan dan semua sektor yang terkena dampaknya, maupun di bidang ekonomi, khususnya yang berkaitan dengan sektor usaha mikro kecil dan berukuran menengah (UMKM) karena pembatasan aktivitas masyarakat luar, dan lebih disarankan untuk mencoba kegiatan dari rumah sesaat sebelum masa kerja rumah atau home work naik. Diharapkan di masa pandemi seperti sekarang ini, masyarakat terus beradaptasi dan belajar khususnya terkait dengan penerapan teknologi khususnya artificial intelligence.

Terdapat 10 besar trend teknologi yang strategis yang di tahun 2020 dikelompokkan dalam 2 bidang yaitu: People-Centric dan Smart Space. Implementai teknologi strategis dalam dunia usaha diantaranya:

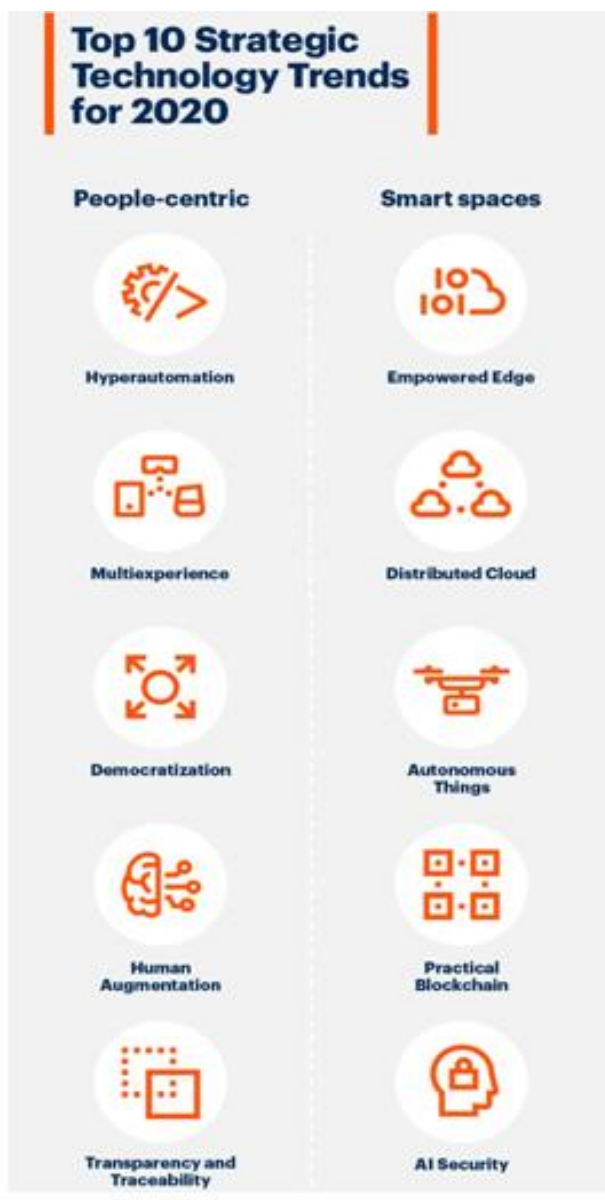

Gambar 2. Tren Teknologi Strategis

a) AR dan VR untuk Media Informasi dan Promosi Elektronik 
Augmented Reality (AR) adalah inovasi yang menggabungkan multi object virtual ke dalam lingkup fisik 3 dimensi dan kemudian memproyeksikan gambar virtual suatu objek. . Pasar dunia sudah mulai didominasi oleh Augmented Reality (AR), sebagai sarana dalam berbisnis. AR digunakan sebagai media promosi produk oleh banyak perusahaan. AR menghasilkan pertumbuhan profit tertentu karena penjual tidak membuat barang tambahan, hanya brosur dan smartphone yang perlu diperiksa di depan pembeli [8]. Trend VR diterapkan di berbagai disiplin ilmu untuk mengoptimalkan visualisasi dan interaksi. VR menyediakan berbagai jenis aplikasi baru sebagai kemampuan akselerasi khusus untuk mengembangkan kinerja dan komoditas produk [9].

\section{b) Computer Vision dan Pattern Recognition}

Para peneliti di NVIDIA pada tanggal 18 Maret 2019 memperkenalkan demo perangkat lunak yang mendukung AI versi beta hasil penelitian mereka di bidang Computer Vision dan Pattern Recognition yang dinamakan NVIDIA GauGAN. Demo aplikasi berbasis web ini dapat mengubah gambar user yang apa adanya menjadi gambar fotorealistik, yang di-generate dari peta segmentasi, yang diberi label sketsa yang menggambarkan tata letak adegan. Aplikasi keluaran NVIDIA Inpainting di atas dapat juga digunakan oleh UMKM untuk keperluan yang kurang lebih sama dengan NVIDIA GauGAN, aplikasi ini sebagai pelengkap untuk editing foto, jadi tidak perlu lagi menyewa jasa tukang edit foto untuk keperluan mendesak atau untuk keperluan editing sederhana seperti pada contoh gambar di atas.

\section{c) Maps Channel untuk Ditambahkan ke Video Company Profile UMKM}

Google Maps kerap digunakan untuk mrnunjukkan lokasi atau rute yang dilalui menuju ke sebuah lokasi, dan Google Street View digunakan untuk menunjukkan suatu lokasi dengan foto 360 derajat yang dapat dilihat atau diputar ke segala arah. Sudah banyak pelaku industri UMKM yang menggunakan dua aplikasi ini, tetapi belum banyak yang tahu bahwa kedua aplikasi tersebut dapat digabung dalam satu aplikasi berbasis web bahkan dapat dianimasikan untuk menunjukkan suatu lokasi dari lokasi tertentu, atau secara mudahnya dapat menganimasikan rute dari titik lokasi A ke titik lokasi B. Pemanfaatan Google Map akan mempermudah customer untuk mencari lokasi usaha yang dituju.

d) Pemanfaatan video call

Pandemi Covid 19 mengharuskan untuk membatasi keiatan di luar ruangan dan berinteraksi secara langsung dengan orang lain, sehingga bagi seorang fotografer tidak dapat lagi untuk memotret model dari sebuah produk untuk ditampilkan di sebuah media promosi. Virtual photoshoot melalui teknologi video call muncul dan menjadi tren yang dapat dilakukan jarak jauh belakangan ini sebagi solusi atas permasalahaan tersebut.

Setelah pemaparan materi, peserta kegiatan webinar diberi kesempatan untuk melakukan tanya jawab dengan narasumber. Hal ini bertujuan agar peserta yang masih belum memahami apa yang disampaikan atau ingin mendapatkan masukan dari narasumber terkait dengan permasalahan yang dihadapi bisa terfasilitasi. Peserta yang mengikuti webinar dan mengisi daftar presensi, mendapatkan sertifikat dan seluruh materi yang dikirimkan melalui email. Untuk konsultasi lebih lanjut, peserta diarahkan untuk menghubungi narasumber secara langsung melalui nomor telepon maupun email yang tertera pada materi setiap pembicara yang telah dikirimkan.

Webinar diikuti berbagai profesi dan instansi diantaranya mahasiswa, dosen, guru, peneliti, pelaku UMKM, serta masyarakat umum. Jumlah peserta yang mengikuti kegiatan webinar dari awal hingga akhir, baik memalui Zoom maupun Youtube sebanyak 514 orang. Hal tersebut menjadi tolak ukur keberhasilan pelaksanaan webinar ini. 


\section{PENUTUP}

\section{Simpulan}

Kegiatan pengabdian media virtual ini telah mengikuti standar pengabdian yang berkontribusi pada pemahaman aplikasi secara praktis. Dari hasil tanggapan angket yang telah disebar dan ateri yang telah dibahas selama beberapa jam dalam bentuk pemaparan materi, pertanyaan dan diskusi oleh beberapa narasumber, peserta pelatihan virtual ini dapat membuka cakrawala dan dapat belajar mencontoh aplikasi augmented reality yang dapat dipraktekkan secara praktis. Tolak ukur keberhasilan pengabdian virtual ini adalah jumlah peserta yang hadir saat acara dari awal hingga sampai di akhir waktu. Selain itu, setelah webinar selesai dilakukan banyak peserta yang memberikan tanggapan positif melalui link presensi yang telah dibagikan, dan berharap webinar serupa agar dapat dilaksanakan kembali di waktu yang akan datang.

\section{Saran}

Dalam pelaksanaan webinar dibutuhkan perencanaan dan persiapan yang matang. Mulai dari proses pemilihan materi yang akan disampaikan, promosi, peralatan yang akan digunakan dalam pelaksanaan webinar, sampai dengan dokumentasi.Hal tersebut dimaksudkan agar dalam pelaksanaannya tidak terjadi kesalahan teknis pada saat acara webinar berlangsung.

\section{DAFTAR PUSTAKA}

Abdurrahman, F. T., "Dampak Covid-19 terhadap UMKM di Indonesia", Jurnal Brand, Vol. 2, no. 1, Juni 2020.

Dwi, A. P.,"50 Persen UMKM Gulung Tikar Akibat Pandemi Covid-19,Oktober 2020 [Online]. Tersedia: https://www.merdeka.com/uang/imbas-pandemi-50-persen-umkm-gulung-tikarakibat-pandemi-covid-19.html [Diakses: 25 Desember 2020]Admin, "Data

UMKM", [Online]. Tersedia: http://www.depkop.go.id/data-umkm [Diakses: 25 Desember 2020]

Verma, A., \& Singh, A., Webinar-Education through digital collaboration. Journal of Emerging Technologies in Web Intelligence, Vol.2, no. 2, pp 131-136, May 2010.

Prawira, Y, "Webinar Sebagai Media Bimbingan Klasikal Sekolah Untuk Pendidikan Seksual Berbasis Online". SSRN Electronic Journal, Vol. No. , pp. 1-19, 2017.

Lili Marlinah, "Peluang dan Tantangan UMKM dalam Upaya Memperkuat Perekonomian Nasional Tahun 2020 Ditengah Pandemi Covid 19”, Jurnal Ekonomi, Vol. 22, no. 2, Juni 2020.

Lala, L. Z., Euis, M. M., Zahra, F. R., "Pelatihan Penggunaan perangkat Berbasis Internet dalam Pengumpulan Data Penelitian Masa Pandemi COVID-19", Educivilia: Jurnal Pengabdian pada Masyarakat, Vol. 1, no. 2, pp. 143-158, Juli 2020

Pamoedji, A. K., Maryuni, \& Sanjaya, R, "Mudah Membuat Game Augmented Reality (AR) dan Virtual Reality (VR) dengan Unity 3D”, Jakarta: PT. Elex Media Komputindo, 2017.

Bahar, Y. N., "Aplikasi Teknologi Virtual Reality Bagi Pelestarian Bangunan Arsitektur”, Jurnal Desain Konstruksi, Vol. 13 no. 2, pp. 34-45, Desember 2014. 